\title{
Teaching Model Reform of Performance Management Course Based on the Theory of Constructivism
}

\author{
Long Cheng \\ School of Government Management, Beijing Normal University, Beijing, China \\ Email: chenglong880507@mail.bnu.edu.cn
}

How to cite this paper: Cheng, L. (2018) Teaching Model Reform of Performance Management Course Based on the Theory of Constructivism. Open Journal of Business and Management, 6, 651-657. https://doi.org/10.4236/ojbm.2018.63049

Received: March 5, 2018

Accepted: June 29, 2018

Published: July 2, 2018

Copyright $\odot 2018$ by author and Scientific Research Publishing Inc. This work is licensed under the Creative Commons Attribution International License (CC BY 4.0).

http://creativecommons.org/licenses/by/4.0/

\section{(c) (i) Open Access}

\begin{abstract}
As the core course of human resource management major, performance management course is highly practical. Based on the theory of constructivism, combining with the practical requirements of enterprise performance management and constructing simulation situation of enterprise performance management, which can make the students understand theory with practice, get better understanding of professional knowledge and master the relevant skills. From the essence of organizational performance simulation method, the performance of communication as an example, the article introduces the operational ideas about constructivism concept in the teaching of performance management, and summarizes the teaching mode experience in organizational context simulation during the performance management teaching process.
\end{abstract}

\section{Keywords}

Constructivism, Organizational Context Simulation, Performance Management, Teaching Model

\section{Introduction}

The major of human resources management is one of applied professions; teachers should pay more attention to the training of practical ability in the process of professional teaching. As a compulsory course in human resource management major, performance management emphasizes the practical training of performance management. Because of the lack of business experience, students do not understand the operation of enterprises and business knowledge in the learning of this course, there is "organizational deficiency" in the curriculum learning process, which largely affects the students to construct the overall cog- 
nition of performance management knowledge [1].

Constructivism is a branch of cognitive psychology, constructivism theory emphasizes student-centered, which not only request students to change from passive recipients of external stimuli and infusing objects of knowledge to subjects of information processing and active construction person of knowledge [2], but also request teachers to change from initiators and implanters of knowledge to helpers and facilitators for students taking the initiative construct meaning.

Constructivism teaching mode emphasizes students as the center, teachers play role of organizer, instructor, helper and promoter in the whole process of teaching, makes students initiative, enthusiastic and creative by using the learning environment elements of context, collaboration and conversation, and finally realizes the construction of current learning effectively [3].

In this mode, the students are active constructors of knowledge; the teacher is organizer, instructor, helper and promoter of meaning construction in teaching process; the creation of learning environment is very important aspect in constructivism teaching mode, in the design of the learning environment, the creation of learning environment should be the real task in daily social life and management activities, and is associated with teaching tasks, rather than abstract task [4]. That is to provide a case based learning environment in the real world during performance management teaching, enable students to construct knowledge through communication and cooperation in the design of the environment, and get the corresponding training and improve by completing the learning task.

The article is organized as follows: First of all, we introduce the teaching mode reform; secondly, we study this model; thirdly, after what has been discussed, we draw the conclusion.

In this article, from the essence of organizational performance simulation method, the performance of communication as an example, the article introduces the operational ideas about constructivism concept in the teaching of performance management, and summarizes the teaching mode experience in organizational context simulation during the performance management teaching process. But further discussion is needed for more complex situations, which requires more scholars' efforts.

\section{The Teaching Mode Reform}

Compared with the traditional teaching mode, in the constructivist teaching mode, students learn initiatively, the efficiency of learning is more embodied in the understanding and application ability of the theory based on the theory of endogenous, rather than the mechanical memory of knowledge in the traditional teaching mode. So the teaching mode of constructivism is consistent with the requirement of talent cultivation in applied universities.

Performance has its behavior, the course of human resources' performance management is mainly concerned about individual performance in their organi- 
zation and a part of performance in team level, therefore, it is closely related to the performance in organizational level. Barnard defined the "organization" as a conscious and collaborative activity system, in fact, it emphasis on the organizational context's profound influence on the individual behavior of employees. Employee performance is based on the organizational structure and the system of task, the essence of employee performance is the consequence of the planned behavior which based on the organizational context. Organizational performance refers to the performance and efficiency when the organization is in the process of achieving its goals. It is often emphasized on the financial performance and administrative performance of the organization. Employee performance is the basis of organizational performance, and organizational performance is closely related to performance management of employee. To understand the performance of individual employees in their organization, it is necessary to have an in-depth understanding of the complex situation of the organizational structure and organizational operation. In the classroom teaching of performance management, it is better to cultivate students' professional ability, let the students to experience the management of enterprise performance activities in the organization situation as much as possible in the classroom, it is one of the important issues of human resource management in the professional teaching. How guide the students to feel the affection of organizational context, teachers should simulate the organization work situation, construct and design organization situation of performance management tasks, to enable students to construct their skills of knowledge about performance management.

\section{Exploration of the Model}

In the practice of course, the organizational context construction should focus on a certain issue in the process of performance management, and set up the simulation situations for students to play various roles, in order to improve the students' ability of professional practice. Teachers need to design the scenario according to teaching content and the background, while students play the roles correspondingly in the plot design on the simulation scene, and put forward some ideas and proposals, or carry out actual operations according to the set of responsibilities, tasks, work procedures, interpersonal coordination etc. This approach sets ability training as the goal, emphasizes the students' subjectivity as the prerequisite, and considers interactive and innovative teaching, learning, and complete simulation as the main characteristics. The basic prerequisite for applying situation simulation method in the teaching is that the teaching contents are fit to be contextualized. The better teaching contents are contextualized, the more effective this method's application will be. Since the maneuverability for performance management course is quite strong, the degree of teaching contents' contextualization will also be high. In the content system of the performance management, adopting the situation simulation method in performance communication, performance appraisal, performance feedback and interview, 
could have twice the result with half the effort.

Performance communication plays a decisive role in performance management. To some extent, communication is the essence and core of performance management, which runs through the performance management cycle from the beginning to the end-we need communication for making performance plans and goals, helping employees to achieve performance goals, year-end assessment, analyzing the reasons and tracking progress. In short, the process of performance management is the continuous communication process between employees and managers in order to improve the performance. Without communication, organizational performance management will become a mere formality. Therefore, in order to make students aware of the importance of communication and master the skills of constructive communication, we can use the situational simulation method to train the students.

\subsection{Situational Setting}

In the performance interview, set three roles: director, subordinate and observer. Director is the leader of the interview; subordinate is interviewee, which can be set for different positions of different types of characters; The tertiary role is observer, the main task of the observer is to observe the director and subordinate's performance in the process of interview which according to the role of the observer.

The observer should observe problems in three aspects: observe the way of talking of director; observe how the talk goes on; evaluate the result of the conversation.

\subsection{Roles Division}

In each group, there will be three rounds of different interviews. In these 3 rounds of interview, every student can play the role of director, subordinate, and observer. And different groups of students can be interspersed with each other to role-play in order to improve the students' participation. For example, the director of the first group can interview the subordinate of the second group and so on.

\subsection{Situational Analysis}

The director of each group can discuss the synopsis of interview, the subordinate of each group can discuss and prepare for the next interview, the observer of each group can discuss and prepared for the role description, to be prepared for the observer. This part need to be considered what knowledge and skills need to be used in the simulation, what kind of plan need to apply, and think about what kind of difficulties will meet.

\subsection{Exercise the Interview of Scenario Simulation}

After each group design the situational analysis, they should start to exercise the 
interview of scenario simulation according to the design. In this process, observers need to remain silent, record the main content based on the observer role at the same time, and give feedback about the performance of two sides at the end of the conversation.

\subsection{Summary and Evaluation}

After the end of summary and share about our interview, the summary of contents as below (Table 1).

After the simulation of situation, the teacher should give students feedback and guidance about their participation in time, including their observation, analysis, discussion, performance in classroom and so on. First, let the students compare the process of communication about different groups, and know about what are the differences and the reasons for the differences. Then, the teacher should tell the students that they should master the technology of communication, such as principle of complete, the principle of symmetry, the principle of responsibility oriented, and the principle of fact oriented.

\section{Conclusions}

In the exploration of the teaching method of performance management based on constructivism, it is found that the students' enthusiasm and participation are generally mobilized. In the performance interview, each student can experience different roles, and the harvest is quite a lot. The teaching effect fully proves that the introduction of multi-role simulation is an effective way to explore the performance management course teaching. Specific experience is summarized as follows:

1) A “student-centered" teaching concept is established. Students are the constructor of their own performance management knowledge through active participation in the situational practice simulation activities to get the support, help

Table 1. The summary of contents.

\begin{tabular}{|c|c|c|}
\hline Supervisor & Under & Observer \\
\hline $\begin{array}{l}\text { 1) How do you feel about } \\
\text { your preparation for this } \\
\text { interview? } \\
\text { 2) Is the process of } \\
\text { communication smooth? } \\
\text { 3) Is this interview } \\
\text { achieving your hope? } \\
\text { Does the interview affect } \\
\text { the mood of the subor- } \\
\text { dinate? } \\
\text { 4) Is there any other need } \\
\text { to add? }\end{array}$ & $\begin{array}{l}\text { 1) How do you feel about } \\
\text { your preparation for this } \\
\text { interview? } \\
\text { 2) Is the process of } \\
\text { communication smooth? } \\
\text { 3) Is the goal of } \\
\text { performance which set } \\
\text { by the supervisor } \\
\text { reasonable? Can you } \\
\text { accept it? }\end{array}$ & $\begin{array}{l}\text { 1) What are the steps in the process of } \\
\text { communication? } \\
\text { 2) Is the prepare of communicate in both } \\
\text { sides sufficient? } \\
\text { 3) How the supervisor's skill of } \\
\text { communication? } \\
\text { 4) What are the key points for leaders to } \\
\text { interview successfully? } \\
\text { 5) What are the problems in the process of } \\
\text { interview? } \\
\text { 6) What principles for subordinates need to } \\
\text { follow in order to make communication } \\
\text { more effective? What are the specific } \\
\text { suggestions for the improvement of } \\
\text { interview? }\end{array}$ \\
\hline
\end{tabular}


and guide from teachers. Therefore, the "teacher-centered" concept must be changed. Teachers should adhere to fully supporting students to develop initiativity and creativity, so that they can have the opportunity to let the various kinds of knowledge externalization in the performance management situation, namely digest and absorb the knowledge in the stimulation process of different performance management sections. They can solve practical problems with the understanding of objective things through the use of interviews, and ultimately achieve self-feedback. Otherwise, even if a teacher teaches everything at his best, it is still a question that how much the students can really learn.

2) The teaching goal of "learning for understanding" is determined. In order to grasp the teaching goal, teachers should have a correct understanding of the teaching objectives first, and then effectively play their roles in the process of achieving this goal. The goal is to learn to understand, teachers are required to transfer the focus from the original "what I teach" to "what students learn". The fundamental significance in performance management course teaching is how to help students to form a deep understanding of knowledge.

3) The teaching process of "learning through situation problem solving" is emphasized. According to the teaching contents of performance management, teachers should propose some performance situation problems appropriately for the students to think and discuss, and try to gradually dig the problems in order to deepen their understanding of the knowledge, and also inspire and guide them to sum up the effective information, so as to discover the laws, so they can correct mistakes and supply their one-sided understanding on performance management. With the characteristics of professional learning, the high level of thinking activities throughout the teaching process while students solving the problems, has always been particularly necessary.

4) The teaching environment of "interaction between teachers and students, students and students" is created. Students are introduced to the situation of utilizing knowledge of performance management. Through the simulation of different aspects of the performance management, it can stimulate students' interest in learning and understanding the meaning about performance management, and improve their ability to use professional knowledge to solve the problem of performance management.

Using situational teaching in classroom is propitious to enhance the cultivation of talents in human resources management. To combine the characteristics of human resource management (it usually pays attention to social psychological and interpersonal communication), it can enhance students to understand the theoretical knowledge better and improve their practical ability through the classroom teaching mode of combination of theoretical knowledge learning and performance context and interpersonal experiences [5]. So it can provide reference and inspiration to construct the talent training system in the human resource management of university.

As the core course of human resource management major, performance 
management course is highly practical. Based on the theory of constructivism, combining with the practical requirements of enterprise performance management, and constructing simulation situation of enterprise performance management, which can make the students understand theory with practice, get better understanding of professional knowledge, and master the relevant skills.

\section{References}

[1] Deng, J.X. (2004) The Idea of Establishing the System of Management Experiment of Scene Simulation. Journal of Guilin University of Electronic Technology, No. 4, 26-29. (In Chinese)

[2] Fang, Z.B. (2012) Performance Management. Renmin University of China Press, Beijing. (In Chinese)

[3] Qiang, G.M. (2007) The Method of Scenario Simulation in Teaching of Human Resource Management. Heilongiiang Education (Higher Education), No. 4, 52-53. (In Chinese)

[4] Fang, Z. (2009) Constructivism Teaching Theory and Its Enlightenment on the Teaching Reform of Higher Education. Contemporary Education Forum, No. 5, 26-28. (In Chinese)

[5] Liu, W.B. and Liu, N. (2014) The Construction and Implementation of the Teaching Method of Scene Simulation and Role Playing-A Case Study of Human Resource Management Course. Modern Educational Science, No. 3, 68-71. (In Chinese) 